\title{
Sustainability empowerment in the workplace: determinants and effects
}

\author{
Christoph Harrach $^{1}$ (D) $\cdot$ Sonja Geiger ${ }^{1}$ Ulf Schrader ${ }^{1}$
}

Received: 6 December 2019 / Revised: 12 March 2020 / Accepted: 23 July 2020 / Published online: 17 August 2020

(c) The Author(s) 2020

\begin{abstract}
There is a dynamic stream of research, which examines why and how employees contribute and respond to corporate social responsibility (CSR). Building on these micro-CSR findings, this article makes a contribution to a better understanding of employee engagement in CSR by considering its determinants and effects. The research centres around the established motivational concept of psychological empowerment in the workplace and applies it to sustainability. The authors propose a model of sustainability empowerment in the workplace (SEW) and empirically test the construct in a comprehensive framework. Results indicate that the sustainability-orientation of employees and the perceived organisational support towards sustainability act as two valid determinants of SEW. It is also shown that SEW has positive effects on job satisfaction and organisational commitment. Further results indicate that the sustainability-orientation of employees plays an important role as a moderator in the relationship between SEW and its effects. In the overall view, the paper contributes to micro-CSR research by showing that SEW is a valid construct that helps to answer why and how employees engage in CSR activities and what positive effects arise therefrom for organisations. The authors give an overview of these contributions and discuss the implications for researchers and practitioners in the field of CSR and HRM.
\end{abstract}

Keywords Corporate social responsibility $\cdot$ Micro-CSR $\cdot$ Sustainability $\cdot$ Human resource management $\cdot$ Psychological empowerment

\section{Introduction}

There is a growing number of scientific publications with a micro level perspective on CSR or corporate sustainability (both terms are used as synonyms in this article), which try to understand the employees' contribution to CSR activities in the workplace. It has become increasingly obvious that motivated employees are needed to anchor sustainable management strategically in organisations (Kramer and Porter 2011; Boudreau 2003; Greening and Turban 2000). Both for science and management, it is necessary to understand the underlying mechanisms of why and how employees are

Christoph Harrach

christoph@harrach.com

Sonja Geiger

sonja.m.geiger@tu-berlin.de

Ulf Schrader

schrader@tu-berlin.de

1 Institute for Vocational Education and Work Studies, Technische Universität Berlin, Berlin, Germany willing to engage in CSR and which effects this creates for organisations. Carmeli et al. (2017, p. 1380) state that current CSR research mostly takes macro-level approaches into account and "focuses on the importance of formal management systems, processes, structures, and certifications". As the integration of sustainability in the corporate DNA is a complex endeavour, a micro-level perspective is needed to understand the role of employees in this transformation process (De Roeck and Maon 2018; Lamm et al. 2015; Ramus and Killmer 2007). Aguinis and Glavas (2012) showed in their meta-analysis of the status quo of CSR research that only about four percent of the scientific publications deal explicitly with the role of employees. This neglect contradicts the findings of various authors (e.g. Lamm et al. 2015; Ramus and Steger 2000; Bliesner et al. 2013) that the role of individual employees is an important factor for successful CSR management. And it is also not considered that some employees do want to participate voluntarily in corporate sustainability activities due to a personal sustainability-orientation as an intrinsic motivation (Blazejewski et al. 2014; Bliesner et al. 2013; Harrach et al. 2014; Hesselbarth and Schaltegger 2014). 
Micro-CSR reflects causes and effects of CSR on an individual level, and three types of micro-level CSR approaches are identified by Gond et al. (2017): 1) individual drivers of CSR engagement, 2) individual processes of CSR evaluation and 3) individual reactions to CSR initiatives. The authors note that the current micro-CSR research focuses "on reactions to CSR, to the detriment of CSR drivers and CSR evaluations" (Gond et al. 2017, p. 227) and an integrated model is necessary to understand the mutual dependencies among those types. Other scholars (Glavas 2016; Rupp and Mallory 2015) emphasize that the relations between employees and CSR are influenced by various mediators (e.g. personal meaningfulness) and moderators (e.g. organisational support) which are also not well understood. De Roeck and Maon (2018, p. 609) emphasise apart from this that "extant empirical research efforts can often be characterized as exploratory, as the theories underlying the potential of CSR to affect employees lack integrative and systematic testing and refinement".

Micro-CSR-research is grounded in organisational psychology (Rupp and Mallory 2015). One highly relevant concept in this area is the main starting point of this paper: Psychological empowerment, which has an "extensive foundational literature, history, and use within organizations" (Maynard et al. 2012, p. 1232). This concept has already been used in micro-CSR research (e.g. Lamm et al. 2015; Tariq et al. 2016; Schrader and Harrach 2013; Harrach et al. 2019). The empowerment framework suggested by Seibert et al. (2011) has the potential to integrate aspects of each micro-CSR perspective identified by Gond et al. (2017) in one model.

This article has three main objectives: First, we apply the concept of psychological empowerment in the workplace to sustainability, deriving an adapted model of "sustainability empowerment in the workplace" (SEW) which represents employee engagement towards sustainability at work. Second, we investigate determinants and effects of SEW in a framework by testing the resulting structural model. Third, we explore moderating effects of sustainability-orientation of employees with regard to SEW's effects on organisational commitment and job satisfaction. The overall objective of the article is to deliver insights into the individual dimensions of CSR engagement, its drivers and consequences.

The article is structured as follows: the introductory part presents a general explanation why employees are important stakeholders for successful CSR management, followed by a presentation of the concept of psychological empowerment alongside its determinants and effects. It is shown that psychological empowerment can be applied to micro-CSR by transforming it to the concept of sustainability empowerment in the workplace (SEW). Based on that, hypotheses on individual employee-specific and organisational determi- nants of SEW as well as on its possible effects on employeespecific attitudes regarding work are developed. These hypotheses form a model that is tested in an empirical study. The insights gained from a representative employee survey in Germany are discussed before finally implications for scientists and managers are presented.

\section{Employees as important stakeholders in CSR}

CSR can only work if it is implemented by employees' everyday behaviour. They should follow new sustainabilityoriented guidelines with regards to e.g. provisioning, energy use, or recycling activities. In addition to merely supporting existing policies, employees can foster CSR by engaging in sustainability-oriented innovation processes (e.g. Buhl et al. 2019). According to Carmeli et al. (2017), the need to understand employee involvement in the CSR management of organisations has two main reasons: first, employee participation in the workplace is a critical factor in achieving key organisational objectives. Second, promoting sustainability is a complex task that requires the involvement of all actors in the organisation. Acknowledging this necessity to involve all corporate stakeholders in CSR, Orlitzky et al. (2011) criticise the overemphasis of the organisational level and general neglect of the aspects of individual contributions in stakeholder research. Ramus and Killmer (2007) argue that participation in CSR for most employees is not formally required, but rather a voluntary task and thus extra-role behaviour. The overall difficulty in engaging employees in CSR is essentially influenced by a personal psychological predisposition (Shamir 1991). Thus, the associated personal evaluation of internal CSR activities is unique and can be seen as "a black box that needs to be opened" (De Roeck and Maon. 2018, p. 611). As employees have different opinions on CSR, insights into the personal preconditions of CSR engagement will be instrumental for their successful implementation.

Two streams of research are relevant for this article to explain the CSR engagement of employees: on the one hand, this article is based on findings from work-life research at the interface of private life and work (from the fields of sociology and HRM). On the other hand, we refer to the social identity theory (from the field of psychology). Both streams, however, are intertwined with one another. The former has shown that there are interdependencies between the life-spheres of employees, so called spill-over effects (Edwards and Rothbard 2000). These reciprocal effects have already been transferred to the field of sustainable HRM research. According to the concept Green Work-Life Balance (Muster and Schrader 2011), there are mutual influences among sustainability-oriented values, attitudes, and 
experiences in private life and behaviour in the workplace. Research shows, that the strength of the spill-over from private life to work depends on the degree of the sustainability-orientation of the employee (Harrach et al. 2014; Weinrich 2014; Lin et al. 2010; Buerke et al. 2013). For this article, the spill-over from private life to work environment may provide a central explanation why employees are engaging in sustainability in the workplace. Ramus and Killmer (2007, p. 558) show for example that "an employee's personal predisposition toward protecting the natural environment has a positive relationship to his/her motivation to engage in corporate greening behaviours". This goes along with findings in social identity theory that there is an individual desire for congruence of values and behaviour between employees and the company (Ashforth and Mael 1989). Previous insights from motivation and engagement theory (e.g. Kahn 1990) show that the more employees can bring in their whole personality to work, the more engaged they will be. There are many factors in the workplace that influence how much of the whole personality can be expressed. CSR activities, e.g. programs for energy saving, recycling or corporate volunteering, can be seen as one factor.

In this context, Rich et al. (2010) have defined four mediators of the CSR-outcomes relationship: psychological safety, psychological availability, values congruence and purpose. Psychological safety is a state of mind, which supports employees to show more of their whole personality at the workplace. It is positively related to perceived organisational support which is also positively related to CSR (Glavas and Kelley 2014). "In other words, CSR can provide nurturing and safe environments in which employees feel a safe space to show up more as who they truly are" (Glavas 2016, p. 5). This alignment of the self-concept of employees with the organisational behaviour leads to a greater congruence of values (Vlachos et al. 2014) and together with improved self-esteem may lead to more fully present employees at work. This so-called psychological availability gives employees a good feeling about themselves because they can recognise that they are part of an organisation that does good. The fourth mediator identified by Rich et al. (2010) is purpose, understood as the feeling of employees that their work is contributing to the common good. According to Glavas and Kelley (2014) the combination of purpose and bringing the whole personality into the workplace could be an important factor to foster CSR activities. The psychological disposition for the wish to contribute to the sustainable development could be a reason, why some employees are attracted by CSR more than others. Those employees with a "green identity" (Blazejewski et al. 2014) have "an intrinsic motivation to protect the environment through work, and aims [sic] for consistency between home and work environmental behaviors"
(Ciocirlan 2016, p. 2). There are different terms for these kinds of employees, such as sustchange agents (Bliesner et al. 2013), sustainability talents (Kirchgeorg 2004), sustainability-oriented employees (Harrach et al. 2014), sustainable intrapreneurs (Schrader and Harrach 2013), green employees (Ciocirlan 2016) or change agents for corporate sustainability (Buhr 2015; Visser and Crane 2010). These employees can play an important role as internal promoters of the sustainability development of organisations when they are proactively integrated in CSR.

Beside the motivational aspects and willingness of employees, Kirchgeorg (2004) states that a strong CSRstrategy requires the ability (competence) and authorisation (self-determination) among executives as well as all other employees. Boudreau (2003) is also referring to this triple concept as an important indicator for the effectiveness in micro-CSR. He criticizes that too little focus is placed on the effectiveness of employee involvement in corporate practice. The three mentioned aspects willingness, ability and authorisation correspond to the dimensions of psychological empowerment in the workplace (Spreitzer 1995). In this construct, the effectiveness demanded by Boudreau (2003) is also considered a fourth dimension: impact.

\section{Sustainability empowerment in the workplace (SEW)}

Psychological empowerment-as defined by Spreitzer (1995) based on Thomas and Velthouse (1990)-examines the individual employees' perceptions of the extent to which they can perform their work in an independent, motivated, and self-effective fashion. It can be seen "as an intrinsic task motivation reflecting a sense of control in relation to one's work and an active orientation to one's work role" (Seibert et al. 2011, p. 981). The active orientation emphasizes that empowerment is a construct that reflects the employees' perception, individual wishes and feelings about the possibilities to shape the work role. According to this, it becomes clear that psychological empowerment is not an organisational intervention, but a state of consciousness perceived by employees (Maynard et al. 2012). According to Spreitzer (1995, p. 1443f.), psychological empowerment manifests in four dimensions, which reflect the willingness, authorisation, ability, and effectiveness of employees' engagement in work-related task fulfilment:

- meaning "is the value of a work goal or purpose, judged in relation to an individual's ideals or standards"

- self-determination "is an individual's sense of having choice in initiating and regulating actions"

- competence "is an individual's belief in their capability to perform activities with skill" 
Fig. 1 Integrated individual and team empowerment framework (Seibert et al. 2011, p. 982)

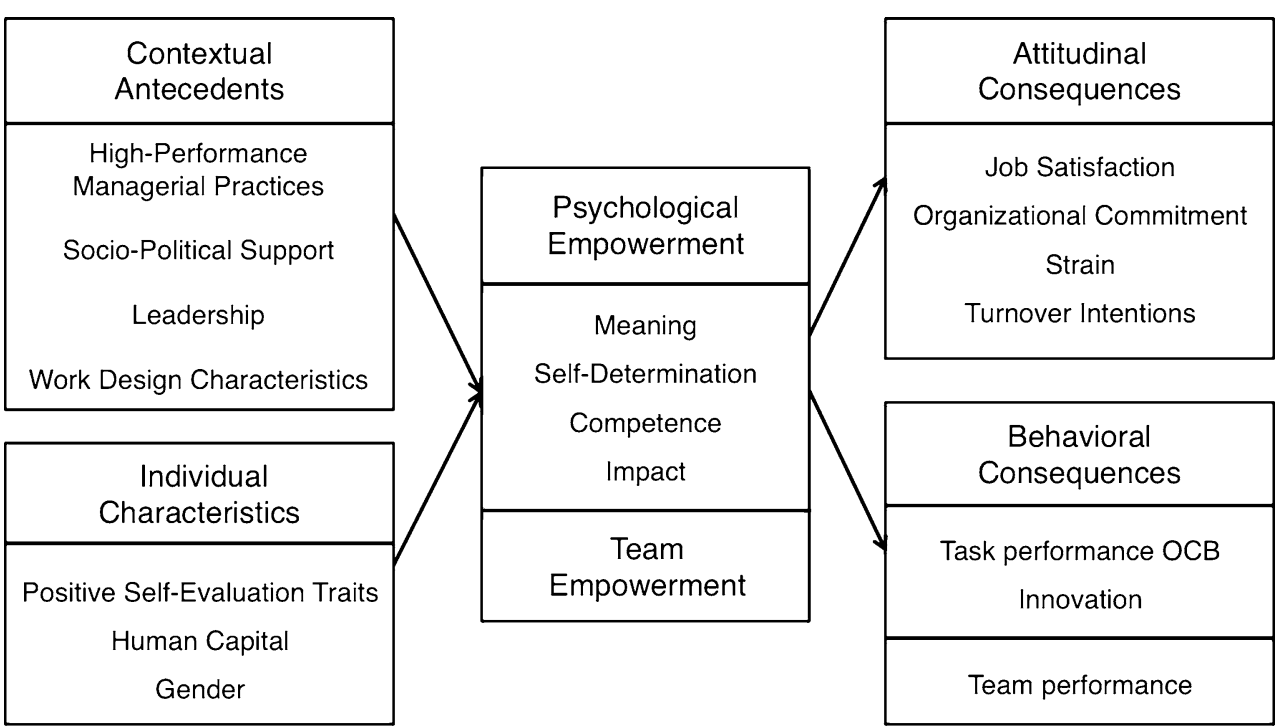

- impact "is the degree to which an individual can influence strategic, administrative, or operating outcomes at work"

It is important to understand that empowerment can only develop in the combination of these four dimensions because" "the highest levels of intrinsic task motivation were proposed to emerge only when all four cognitions are high" (Seibert et al. 2011, p. 981). A comprehensive framework of psychological empowerment, its antecedents and consequences, has been proposed by Seibert et al. (2011) (see Fig. 1).

Empowerment depends on the individual characteristics of the employees and on the organisational framework conditions in which the employees are embedded (Seibert et al. 2011). It can have a positive impact on various success factors in HRM, e.g. job satisfaction (e.g. Carless 2004; Harris et al. 2009; Liden et al. 2000) and organisational commitment (Brammer et al. 2007; Peterson 2004).

Psychological empowerment has already been used in micro-CSR research (e.g. Lamm et al. 2015; Tariq et al. 2016, Schrader and Harrach 2013; Harrach et al. 2019). We assume that the shown empowerment framework in Fig. 1 may reflect central aspects of each of the three micro-CSR approaches identified by Gond et al. (2017) from a different angle. The core of the framework with the four empowerment dimensions may cover the individual evaluations of CSR. Gond et al. (2017, p. 231) mean by evaluations "the cognitive and affective processes by which people gather and organize information related to organizations' CSR initiatives to form judgments about the initiatives, experience emotions resulting from their perceptions." The antecedents of the empowerment framework reflect aspects which Gond et al. (2017) consider drivers of CSR. They define drivers as "factors that operate as predictors of, motives for, or forces that trigger CSR engagement" (Gond et al. 2017, p. 228). The attitudinal and behavioural consequences of the empowerment framework may stand for the individual reactions to CSR initiatives. Gond et al. (2017, p. 233) acknowledge that "CSR triggers multiple attitudes among and behaviors by individuals" and also distinguish these effects in attitudinal and behavioural outcomes.

Behind this background, we define sustainability empowerment in the workplace (SEW) as the sustainability specific form of psychological empowerment as follows:

Sustainability empowerment in the workplace (SEW) describes an employee's CSR engagement by reflecting their sense of control in relation to their work in the context of sustainability

SEW can be seen as an active orientation to one's work role that reflects the employees' perception, how their wishes and feelings about sustainability enables them to shape their work role by engaging in CSR activities. According to this, SEW may answer the question how employees evaluate their willingness and ability to engage in sustainability activities in the workplace, manifesting itself in the following four dimensions:

Sustainability-meaning is the value of a work purpose, judged in relation to an individual's sustainability ideals or standards. It describes the willingness of employees to integrate their sustainability-orientation in the workplace. This spill-over from private to work could be seen as a motivational factor, why some employees engage in CSR. Organisational activities in CSR may lead to a perceived strong congruence between the values, especially for sustainability-oriented employees (Rich et al. 2010; Harrach et al. 2014; Glavas and Kelley 2014). According to the social identity theory, a positive congruence of values leads to 
an improved self-esteem (Ashforth and Mael 1989) that is positively related to empowerment.

Sustainability-self-determination is an individual's sense of having a choice in initiating and regulating actions towards sustainability in the workplace. This dimension is the degree of freedom to bring in sustainability-related aspects of the whole personality to work. It indicates how much the employee feels allowed to do so and depends on the extent to which an organisation integrates its employees into sustainable development. Lamm et al. (2015, p. 211) argue that "feelings of self-determination will be increased as the employee will be able to make choices" and they found empirical evidence that psychological empowerment partially mediated the relationship between this support and job satisfaction.

Sustainability-competence is an individual's belief in their capability to perform activities in the context of sustainability with skill. Ramus and Killmer (2007, p. 557) found evidence that "one's belief in one's own ability to successfully perform the action is an important motivational driver and appears to be predominant in the context of employee performance of extra-role pro-social behaviours". The development of employee skills is one of the HRM's core tasks in micro-CSR. Programs for competence building as employee education or trainings have shown a positive influence in the employee's engagement in CSR (e.g. Ramus and Steger 2000; Galpin et al. 2015). Based on the findings, the authors assume that fostering sustainability-oriented competences will foster SEW.

Sustainability-impact is the perceived degree to which an individual can influence strategic, administrative, or operational sustainability outcomes at work. It shows the influence of employees on the CSR strategy and activities and measures the degree of perceived self-efficacy of the employees relating to CSR. Lamm et al. (2015, p. 208) state in this context "As a result, the cumulative environmental impact of a company is in part affected by discretionary decisions made by individual employees every day. While the impact of one individual's decisions might be small, in the aggregate, the impact is significant". This fourth di- mension of SEW is influenced by various factors that enhance employees' feelings of impact "because of the greater availability of the material resources, power, and influence needed to accomplish tasks and work-related goals" (Seibert et al. 2011, p. 984).

For an empirical validation, the framework proposed by Seibert et al. (2011) (as shown in Fig. 1) needs specification with regards to SEW. Following the preliminary work of Lamm et al. (2015), who also adapted the framework of Seibert et al., we also neglect the team perspective and use only one contextual determinant. Since the sustainability-orientation of employees (SOE) and their spill-over to the workplace play a central role for SEW, we supplement the model of Lamm et al. (2015) with this individual determinant. At the level of consequences, we focus only on the attitudinal effects. We have made this reduction because we want to make a contribution to explaining the retention of talented employees as an effect of SEW, in particular for sustainability-oriented employees. We have selected job satisfaction and commitment as the two effects with the highest correlation to empowerment in the meta-analysis of Seibert et al. (2011). We expect the effects of SEW will be specifically strong for employees with high SOE. Fig. 2 shows an overview of the resulting SEW framework.

\section{Hypotheses}

In this section, the relations between SEW and its selected determinants and effects (as shown in Fig. 2) are specified in testable hypotheses.

\subsection{Determinants of SEW}

\subsubsection{Perceived organisational support towards sustainability (POS-S)}

Various authors (e.g. Glavas 2016; Lamm et al. 2015) state that organisational support can foster employee engagement in CSR. Ramus and Killmer (2007) found evidence that this

Fig. 2 Sustainability Empowerment in the Workplace (SEW) framework

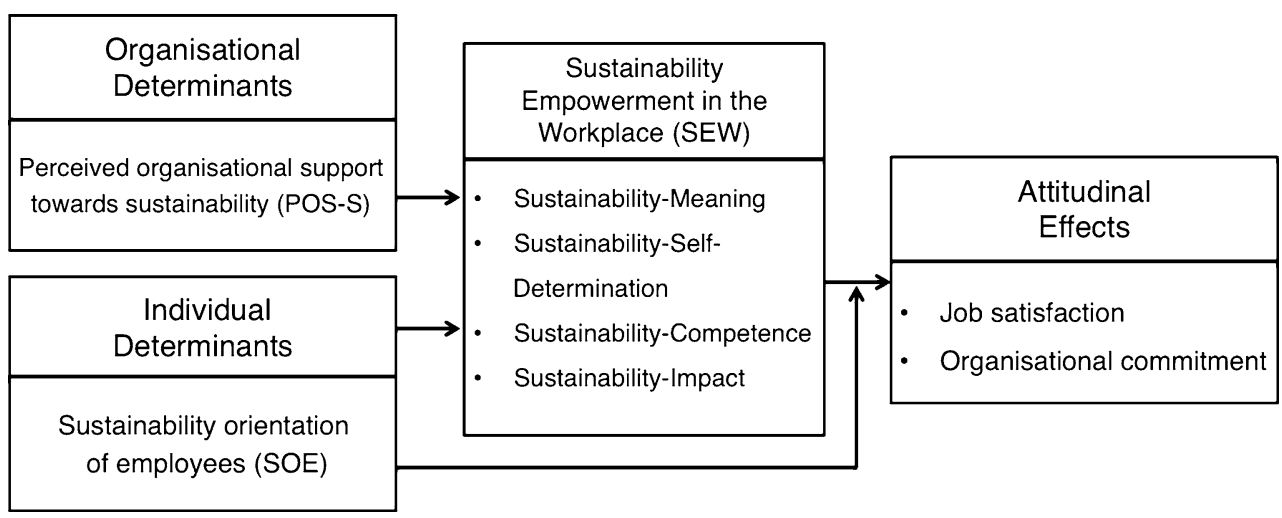


is a dominant motivational driver to extra-role behaviours (e.g. participating in CSR initiatives). De Roeck and Maon (2018) argue that perceived organisational support (POS) is a central factor in micro-CSR. It "represents generalized beliefs made by employees concerning how much the organisation values their contributions" (Rhoades et al. 2001, p. 825). Lamm et al. (2015) have already adapted POS to CSR. They named it "Perceived Organisational Support towards the Environment" (POS-E) and defined it as follows: "the specific beliefs held by employees concerning how much the organisation values their contributions toward sustainability" (Lamm et al. 2015, p. 209). This support acts as the central determinant for SEW. It could be assumed that employees who perceive such support have a stronger feeling of being sustainability empowered.

H1 The perceived organisational support towards sustainability (POS-S) is positively related to SEW.

\subsubsection{Sustainability-orientation of employees (SOE)}

A sustainability-orientation of employees (SOE) results from their ecological, social, and economic attitudes and behaviours following the triple bottom line approach (Elkington 2013). We do understand this self-evaluation trait as an individual determinant of empowerment in reference to Seibert et al. (2011, p. 984) that "is thought to represent the fundamental appraisal one makes about one's worthiness, competence, and capabilities in relation to one's environment" towards sustainability at the workplace. There are findings in the literature that self-evaluation traits "influence the types of jobs and occupations people select" (Judge and Hurst 2007, p. 1213) to pursue work goals in harmony with employees' values, attitudes, and intrinsic motivations (Sheldon and Elliot 1999). This is in line with microCSR research, which shows that SOE has an influence on employer choice (e.g. Weinrich 2014; Kirchgeorg 2004; Buerke et al. 2013; Greening and Turban 2000). Different scholars (e.g. Muster and Schrader 2011; Rich et al. 2010; Harrach et al. 2014) show that attitudes and behaviour in the context of ecological, economic, and social issues are transferred from private life to work (see Sect. 2). It is therefore assumed that the sustainability-orientation of employees has a positive impact on SEW, in particular on the dimension of "sustainability-meaning", which "involves a fit between the requirements of the work role and personal beliefs, values, and behaviours" (Spreitzer 1995, p. 1443) in the context of sustainability.

H2 The sustainability-orientation of employees (SOE) is positively related to SEW.

\subsection{Attitudinal effects of SEW}

As mentioned before, the article focuses on two effects, namely organisational commitment and job satisfaction. These HRM success indicators have the highest correlation with empowerment in the study of Seibert et al. (2011). There are many references in the micro-CSR literature relating the effects of CSR on commitment (e.g. Brammer et al. 2007; Turker 2009; Hofman and Newman 2014; Farooq et al. 2014) with job satisfaction (e.g. Valentine and Fleischmann 2008; De Roeck et al. 2013, Dhanesh 2014). This could be due to an increased credibility of the organisation (Farooq et al. 2014). "Recent research efforts at the micro-level have also contributed to the business case of CSR by highlighting the positive impact of perceived CSR on employees' job satisfaction" (De Roeck and Maon 2018, p. 615). It is assumed that SEW as an intrinsic task motivation reflecting the employees' CSR engagement in relation to the work has a positive effect on the abovementioned HRM success indicators.

H3 SEW is positively related to job satisfaction.

H4 SEW is positively related to organisational commitment.

\subsection{Moderating effect of the sustainability- orientation of employees (SOE)}

There are findings that establish employees' specific individual differences as moderators in micro-CSR research (e.g. Jones et al. 2019). Different types of employees have different needs and motivations regarding CSR. The assumed moderating effects could be seen in the context of the social identity theory as an individual confirmation that an employee is working in the right company when it comes to their personal perception of sustainability (Blazejewski et al. 2014). Peterson (2004) and Turker (2009) discovered that the relation between CSR and commitment is more pronounced in the group of sustainability-oriented employees. Social identity theory provides evidence that when employees perceive that organisational values fit their own, they are more satisfied (Carmeli et al. 2017). Based on these findings, we assume that the relationships between SEW and its effects should be stronger in the group of sustainabilityoriented employees.

H5 The relation between SEW and job satisfaction is moderated by SOE.

H6 The relation between SEW and organisational commitment is moderated by SOE. 


\section{Method}

The hypotheses were tested via structural equation modelling (SEM). The method allows to test measurement models for latent variables and structural models for the relationship of these variables simultaneously. For the analysis, the software SmartPLS (Ringle et al. 2015) was used for the variance analytical approach (Wold 1982) and the derived "partial least square" (PLS) method (Lohmöller 1989).

\subsection{Measurement instruments}

$S E W$ was operationalised on the basis of the four-dimensional questionnaire by Spreitzer (1995) with 12 items (Cronbach's Alpha $=0.94)$. Each was reworded to integrate the topic sustainability.

$P O S-S$ was based on the five items POS-E scale by Lamm et al. (2015) (Cronbach's Alpha $=0.78$ ).

$S O E$ was developed using three sub-scales for the triple bottom line approach (Elkington 2013): Six items of the "Green Scale" of Haws et al. (2014) for the ecological dimension, six items for the social dimension based on the "Green Scale" that was adapted to social values and three items of the "frugality scale" (Lastovicka et al. 1999) for the economic dimension, (Cronbach's Alpha $=0.93$ ).

Job satisfaction was operationalised according to Valentine and Fleischmann (2008) with three items (Cronbach's Alpha = 0.87).

Organisational commitment was measured using three items of the Bentein et al. (2002) scale (Cronbach's Alpha $=0.92$ ). All scale items were rated on a 5-point Likerttype scale from (1) Agree to (5) Disagree. A complete list of items is shown in Appendix A.

\subsection{Sample}

In the empirical study an online survey was conducted. The participants were recruited through the online panel of the German market research provider Respondi AG. The panel meets the quality standards of the European Soci- ety for Opinion and Market Research and is certified by ISO 26362 (Respondi AG 2018). The group of working adults older than 18 years was selected from this panel. The study was conducted with 1252 employees; it took place in January 2018. The sample meets the criteria of online representativeness based on gender and age for Germany. $52.2 \%$ of the respondents were male and the age groups were $18-29$ years (13.8\%), 30-49 years (48.8\%) and older than 50 years $(37.4 \%)$.

\section{Results}

As SEW is a novel concept, we checked the quality of the measurement model(s) before analysing the hypothesis, the moderating and mediating effects in the structural (inner) model. The analysis found that the measured constructs were all both reliable and valid. All associated quality criteria and the complete process for a multistage PLS analysis with the associated quality criteria are shown completely in Appendix B.

The following results can be presented in the analysis of the structural model referring to the hypothesis (Table 1).

A highly significant and strongly positive relationship between POS-S and SEW was found (path weight 0.62) confirming H1. The relationship between the individual determinants SOE and SEW was also highly significant (with a lower path weight of 0.35 ), thus confirming $\mathrm{H} 2$. The results show that SEW is positively and significantly related to job satisfaction (path weight $0.34, \mathrm{H} 3$ confirmed,) and organisational commitment (path weight $0.43, \mathrm{H} 4$ confirmed). The explanatory power of the model shows that the latent variable SEW is substantially explained by its determinant variables $\left(R^{2}=0.66\right)$. The predictive power for the effects of SEW on job satisfaction $\left(R^{2}=0.12\right)$ and commitment $\left(R^{2}=0.18\right)$ is rather low. To test the moderating effect of SOE, the sample was split in four quartiles, resulting in a 0.25 -quartile (high sustainability-oriented employees, $n=328$ ) and a 0.75 -quartile (low sustainability-oriented employees, $n=318$ ). In the group of highly sustainability-ori-

Table 1 Overview of main hypotheses and results

\begin{tabular}{|c|c|c|c|c|c|}
\hline \multicolumn{2}{|c|}{ Hypotheses } & \multirow{2}{*}{$\begin{array}{l}\text { Path coeff } \\
0.62\end{array}$} & \multicolumn{3}{|l|}{$p$-value } \\
\hline $\mathrm{H} 1$ & POS-S is positively related to SEW & & $<0.01$ & - & - \\
\hline $\mathrm{H} 2$ & SOE is positively related to SEW & 0.35 & $<0.01$ & - & - \\
\hline $\mathrm{H} 3$ & SEW is positively related to job satisfaction & 0.34 & $<0.01$ & - & - \\
\hline $\mathrm{H} 4$ & SEW is positively related to organisational commitment & 0.43 & $<0.01$ & - & - \\
\hline \multicolumn{2}{|c|}{ Hypotheses } & $\begin{array}{l}\text { Path coeff. } \\
\text { SOE high }\end{array}$ & $\begin{array}{l}\text { Path coeff. } \\
\text { SOE low }\end{array}$ & $\begin{array}{l}\text { Path coeff. } \\
\text { diff }\end{array}$ & $p$-value diff \\
\hline H5 & $\begin{array}{l}\text { The relation between SEW and job satisfaction is moder- } \\
\text { ated by SOE }\end{array}$ & 0.47 & 0.16 & 0.31 & $<0.01$ \\
\hline H6 & $\begin{array}{l}\text { The relation between SEW and organisational commit- } \\
\text { ment is moderated by SOE }\end{array}$ & 0.57 & 0.21 & 0.36 & $<0.01$ \\
\hline
\end{tabular}


Fig. 3 Path coefficients and explanatory power in the SEW framework (in brackets: values for subsamples, employees with low sustainability-orientation vs. employees with high sustainability-orientation)

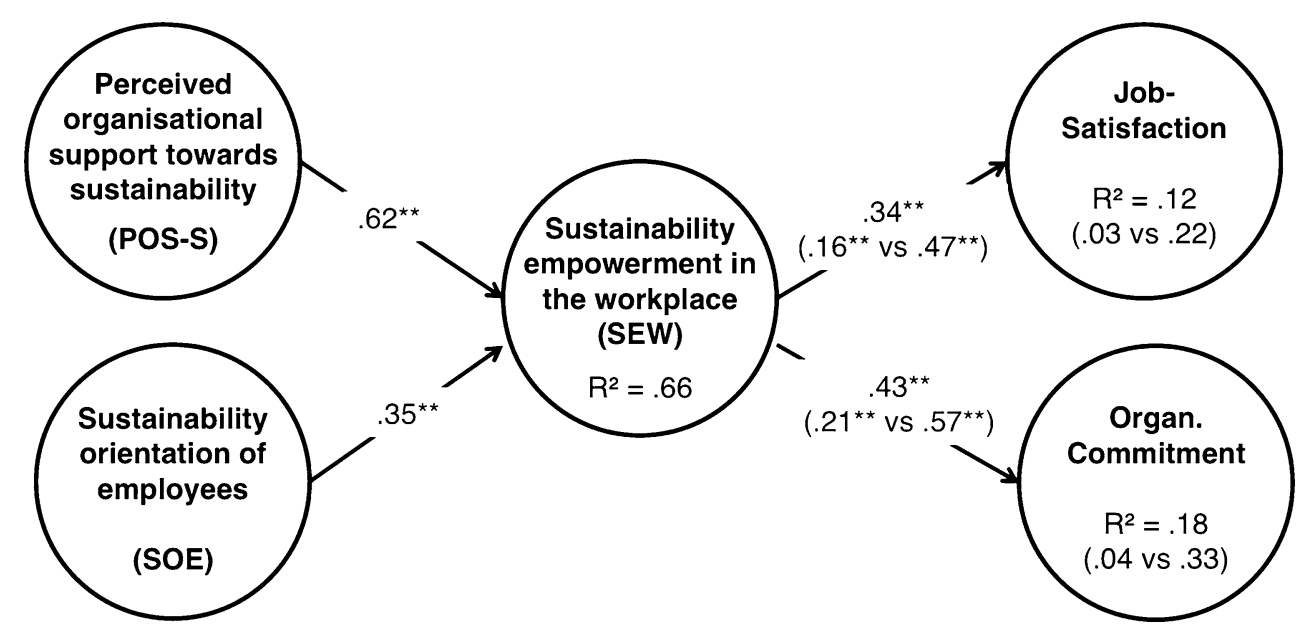

ented employees, the model has an increased explanatory contribution to the variables affected by SEW (job satisfaction $\mathrm{R}^{2}=0.22$ and commitment $\mathrm{R}^{2}=0.33$ ) compared to the overall sample. The results corroborate that SOE acts as a moderator for the attitudinal effects of SEW. This means that the effects of SEW are significantly more pronounced in the group of sustainability employees, which confirms H5 and H6.

Fig. 3 shows central empirical findings in the SEW structural model.

Mediating effects of SEW between its determinants and effects could only be found towards organisational commitment. A partial effect for POS-S and a full effect for SOE has been revealed.

An acceptable quality of the model can be confirmed with the SRMR (Standardized Root Mean Square Residual) value of 0.09 and other criteria demanded by Henseler et al. (2014) (see further discussion of the model quality in the appendix).

\section{Discussion}

\subsection{Research contributions}

With this research paper, the established construct of psychological empowerment has been applied to micro-CSR: sustainability empowerment in the workplace (SEW). SEW stands for an active reflection of employees of how their individual wishes and feelings about sustainability enables opportunities to engage in CSR in their work role. Determinants and effects of SEW were proposed and tested empirically in a comprehensive SEW framework. All related hypotheses have been confirmed, which shows the relevance of the considered drivers and reactions.

This work is a continuation of former scientific microCSR approaches that found that the original empowerment construct acts as a mediator between organisational support for the environment and commitment in the group of sustainability-oriented employees (Lamm et al. 2015). This article goes a few steps further and makes the following contributions to the theory. First, the original empowerment construct was fully adapted to make employee-specific engagement in CSR measurable, thus creating a new relevant construct. Second, two central antecedents of empowerment identified by Seibert et al. (2011) were adjusted to micro-CSR. The empirical findings demonstrate that this adjustment can explain organisational and individual determinants towards employee participation in CSR. Third, the SEW framework was tested in a representative employee survey. The results show that the assumed relationships are highly significant. SEW is substantially explained by its determinants POS-S and SOE $\left(\mathrm{R}^{2}=0.66\right)$. The predictive power of SEW for job satisfaction $\left(\mathrm{R}^{2}=0.12\right)$ and commitment $\left(\mathrm{R}^{2}=0.18\right)$ is rather low for the average employees, but higher for those with a strong sustainability-orientation $\left(\mathrm{R}^{2}=0.22 / 0.33\right)$. Thus, it could be demonstrated that there are significant group differences between sustainability-oriented and non-sustainability-oriented employees in the effects of SEW towards job satisfaction and commitment. Our results are not directly comparable with the results of Lamm et al. (2015) due to different measurement methods. However, it seems evident that the relationship between POS-S and SEW is stronger than POS-S and Spreitzer's established empowerment construct used by Lamm et al. (2015). It becomes also clear that the effects of the conventional empowerment used by Lamm et al. (2015) on job satisfaction are more pronounced than these effects of SEW in our framework.

\subsection{Limitations and suggestions for future research}

The tested SEW framework does not cover all the preconditions detected by the meta-analysis of Seibert et al. (2011) 
but considers relevant determinants in the field of microCSR research. Here, amendment in a second iteration of the SEW could include e.g. leadership support towards sustainability as another relevant factor to anchor sustainability in organisations (e.g. Weaver et al. 1999). Another limitation of this article is that the authors have focused on individual psychological empowerment and not on team empowerment. The team empowerment perspective could be another important path to insight, as the development of corporate culture is a relevant challenge in developing CSR at all levels in the organisation (e.g. Hejjas et al. 2018).

In addition, we have not tested relationships between the determinants and effects with each of the dimensions of empowerment. Although psychological empowerment has proven to be a valid unitary second-order construct, there are also scientific findings that consider determinants and effects of the individual four dimensions. E.g. Kraimer et al. (1999) and Harrach et al. (2014) found a direct positive relationship between the dimension impact and organisational commitment. Spreitzer et al. (1997) found evidence that the two dimensions competence and impact are the most powerful indicators predicting employee effectiveness. An analysis on the level of dimensions could also provide a further insightful path for future research, in particular, the implementation of employee-centred CSR interventions in organisations.

\subsection{Practical consequences and recommendations for managers}

In summary, the findings deliver wide practical implications for managers. Our SEW framework gives a broad overview of determinants and effects of employee engagement in CSR. The results show that the congruence of values is one aspect why some employees are willing to engage in CSR. Our suggestion is therefore to identify those employees who voluntarily want to contribute to CSR. For the implementation of such a profiling, e.g. the topic SOE could be taken up in employee surveys or used in in job interviews for new employees. To promote the self-esteem of those employees, it could be useful to give this group the opportunity to present their private commitment to sustainability at work. This valuation of a sustainability-orientation in the workplace leads to the second aspect namely perceived organisational support towards sustainability, which has a strong impact on employees' engagement. For example, companies can support their employees in behaving more sustainably in the workplace (e.g. through appropriate sustainable consumption offers) or develop conditions for sustainable engagement in the workplace. This could be done e.g. by releasing employees from their formal work duties for a certain period in order to develop new sustainability initiatives (e.g. through corporate volunteering programs). Another relevant factor in the organisational support is the topic leadership. The authors see leaders' support as an important factor in promoting CSR. Here, appropriate leadership training could be activities to develop an awareness of the importance of this support. This support could also manifest in building employee-specific competencies for sustainability e.g. by integrating sustainability into the education and training program. Additionally, it is recommended that organisations proactively involve employees in sustainability management. In practice, this could mean initiating sustainability-related competitions internally to reward viable ideas or firmly integrating the topic of sustainability within the company's suggestion programme. Furthermore, the involvement of employees in innovation workshops on CSR (Buhl et al. 2019), which has already shown positive effects on impact perception (Harrach et al. 2019) can also be recommended. To trigger the perception of this organisational support towards sustainability, adequate internal communication of CSR accomplishments is crucial (Schrader and Harrach 2013).

In summary, this article offers an empirically tested framework to plan micro-CSR activities. It has demonstrated that motivating and enabling employees to engage in CSR activities through organisational support can have a positive impact on organisational commitment and job satisfaction especially for employees with a strong sustainability-orientation.

Funding Open Access funding provided by Projekt DEAL.

Conflict of interest C. Harrach, S. Geiger and U. Schrader declare that they have no competing interests.

Open Access This article is licensed under a Creative Commons Attribution 4.0 International License, which permits use, sharing, adaptation, distribution and reproduction in any medium or format, as long as you give appropriate credit to the original author(s) and the source, provide a link to the Creative Commons licence, and indicate if changes were made. The images or other third party material in this article are included in the article's Creative Commons licence, unless indicated otherwise in a credit line to the material. If material is not included in the article's Creative Commons licence and your intended use is not permitted by statutory regulation or exceeds the permitted use, you will need to obtain permission directly from the copyright holder. To view a copy of this licence, visit http://creativecommons.org/licenses/by/4. $0 /$.

\section{Appendix A}

\section{Operationalisation of the latent variables}

\section{Operationalisation of SEW}

The $S E W$ was operationalised on the basis of the four-dimensional questionnaire by Spreitzer (1995) with 12 items, each of which was reworded to integrate the topic sustain- 
ability. Sustainability-meaning: 1) It is very important to me to contribute sustainable behaviour from my private life in the workplace. 2) My attitudes to sustainability are personally meaningful to me at work. 3) It is meaningful to me to bring my private experiences on sustainability into the workplace. Sustainability-competence: 4) I am confident about my ability to put my private experience of sustainability into the workplace. 5) I am self-assured about my capabilities to integrate my private attitudes towards sustainability in the workplace. 6) I am convinced of my ability to practice sustainability during working hours. Sustainability-self-determination: 7) I have significant autonomy in determining how I bring in my private experience of sustainability in the workplace. 8) I can decide on my own how to bring in private experiences regarding sustainability in the workplace. 9) I considerable opportunity for independence to apply my private knowledge about sustainability in the workplace. Sustainability-impact: 10) My impact on what happens in my company in terms of sustainability is large. 11) I have a great deal of control of my employer over what happens regarding sustainability. 12) I have significant influence over what happens in my company regarding sustainability.

\section{Operationalisation of contextual antecedents (determinants of SEW)}

The construct "Perceived Organisational Support towards Sustainability" (POS-S) was developed according to the approach of "Perceived Organisational Support towards the Environment" (POS-E) by Lamm et al. (2015) with the following items: 1) I feel that I am able to behave as sustainably as I would like in my company. 2) My company is not interested whether I behave sustainably. 3) My company provides incentives to reduce the consumption of nonrenewable resources. 4) I do not feel that I am making a positive contribution to the environment through work in my company. 5) My sustainability activities are valued in my company.

\section{Operationalisation of individual characteristics (determinants of SEW)}

A sustainability-orientation of employees (SOE) consists of their ecological, social and economic attitudes and behaviours. For the ecological dimension, we used the "Green Scale" of Haws et al. (2014) with the following items: 1) It is important to me that the products I use do not harm the environment. 2) I consider the potential environmental impact of my actions when making many of my decisions. 3) My purchase habits are affected by my concern for our environment. 4) I am concerned about wasting the resources of our planet. 5) I would describe myself as environmentally responsible. 6) I am willing to be inconvenienced in order to take actions that are more environmentally friendly. For the social dimension, the "Green Scale" of Haws et al. (2014) was adapted to social values and consumer behaviour and used with the following items: 1) It is important to me that the products I use were made without child labour. 2) I consider the potential social impact of my actions when making many of my decisions. 3) My purchase habits are affected by my concern for fair working conditions in production. 4) I am concerned about social injustice in the world. 5) I would describe myself as socially responsible. 6) I am willing to be inconvenienced in order to act socially and fairly. For the economy dimension, we used parts of the "frugality scale" (Lastovicka et al. 1999) with the following three items: 1) If you can re-use an item you already have, there's no sense in buying something new 2) There are things I resist buying today, so I can save for tomorrow. 3) Making better use of my resources makes me feel good.

\section{Operationalisation of attitudinal consequences (effects of SEW)}

The constructs were operationalised as follows: The job satisfaction was operationalised according to Valentine and Fleischmann (2008) with the following items (Cammann et al. 1983; Rich 1997): 1) All in all, I am satisfied with my job. 2) In general, I like working at my company. 3) In general, I don't like my job (reverse scored). The organisational commitment was based on the scale of Bentein et al. (2002): 1) I really feel close to my company. 2) My company has a great personal significance for me. 3) I am proud to work for my company.

\section{Appendix B}

\section{Additional information about the model}

\section{Analysis of the outer (measurement) model}

\section{a) Reliability of the Latent Variables (Table B.1)}

The results show that the required quality standards (Chin, 1998; Höck and Ringle 2006; Henseler et al. 2012; Daskalakis and Mantas 2008; Fornell and Larcker 1981) for the present reflective measurement model are all fulfilled.

\section{b) Validity of the Latent Variables (Table B.2)}

Thus, it can be determined for this test step that the measurement (outer) model of measured constructs was constructed both reliably and validly. In summary, it can be concluded that the test of the entire measurement model is positive. 
Table B.1 Analysis of Composite Reliability (CR), Average Variance Extracted (AVE) and Cronbach's Alpha

Table B.2 Analysis of the Fornell and Larcker (1981) discriminant validity criterion

Table B.3 Analysis of path coefficients and their significance

Table B.4 Multi-group analysis of path coefficients and significance (effects of SEW)

\begin{tabular}{llll}
\hline Latent variable & Composite reliability & $\begin{array}{l}\text { Average Variance Extracted } \\
\text { (AVE) }\end{array}$ & $\begin{array}{l}\text { Cronbach's } \\
\text { Alpha }\end{array}$ \\
\hline SOE & 0.94 & 0.51 & 0.93 \\
POS-S & 0.86 & 0.61 & 0.78 \\
SEW & 0.95 & 0.61 & 0.94 \\
Job satisfaction & 0.92 & 0.79 & 0.87 \\
Organisational Commitment & 0.95 & 0.86 & 0.92 \\
\hline
\end{tabular}

\begin{tabular}{lllll}
\hline Latent variable & $\begin{array}{l}\text { Average Variance } \\
\text { Extracted (AVE) }\end{array}$ & $\sqrt{\mathrm{AVE}}$ & $\begin{array}{l}\text { Max correlation } \\
\text { with another } \\
\text { latent variable }\end{array}$ & $\begin{array}{l}\text { Fornell-Larcker } \\
\sqrt{\mathrm{AVE}}>\text { max. Corr }\end{array}$ \\
\hline SOE & 0.51 & 0.71 & 0.56 & Approved \\
POS-S & 0.61 & 0.78 & 0.74 & Approved \\
SEW & 0.61 & 0.78 & 0.74 & Approved \\
Job satisfaction & 0.79 & 0.89 & 0.82 & Approved \\
$\begin{array}{l}\text { Organ. Commit- } \\
\text { ment }\end{array}$ & 0.86 & 0.93 & 0.51 & Approved \\
\hline
\end{tabular}

Determinants of SEW

Hypotheses

Latent variables

Path coefficients

$p$-value

$\mathrm{H} 1$

POS-S $\rightarrow$ SEW

0.62

$<0.01$

$\mathrm{H} 2$

$\mathrm{SOE} \rightarrow \mathrm{SEW}$

0.35

$<0.01$

Effects of SEW

Hypotheses

Latent variables

Path coefficients

$p$-value

H3

SEW $\rightarrow$ Job satisfac- $\quad 0.34$

$<0.01$

tion

H4

$\mathrm{SEW} \rightarrow$ Organ.

0.43

$<0.01$

\begin{tabular}{|c|c|c|c|c|c|}
\hline \multicolumn{6}{|c|}{ Moderated Consequences (effects) of SEW } \\
\hline Hyp & Latent variables & $\begin{array}{l}\text { Path } \\
\text { coefficients } \\
\text { SOE high }\end{array}$ & $\begin{array}{l}\text { Path } \\
\text { coefficients } \\
\text { SOE low }\end{array}$ & $\begin{array}{l}\text { Path } \\
\text { coefficients } \\
\text { difference }\end{array}$ & $\begin{array}{l}p \text {-value } \\
\text { difference }\end{array}$ \\
\hline H5 & $\begin{array}{l}\mathrm{SEW} \rightarrow \text { Job } \\
\text { satisfaction }\end{array}$ & 0.47 & 0.16 & 0.31 & $<0.01$ \\
\hline H6 & $\begin{array}{l}\mathrm{SEW} \rightarrow \text { Organ. } \\
\text { commitment }\end{array}$ & 0.57 & 0.21 & 0.36 & $<0.01$ \\
\hline
\end{tabular}

Table B.5 Analysis of the explanatory and predictive power of the model

\begin{tabular}{llll}
\hline Latent variable & R square & $\begin{array}{l}\text { R square } \\
\text { SOE high }\end{array}$ & $\begin{array}{l}\text { R square } \\
\text { SOE low }\end{array}$ \\
\hline Job satisfaction & 0.12 & 0.22 & 0.03 \\
$\begin{array}{l}\text { Organ. commit- } \\
\text { ment }\end{array}$ & 0.18 & 0.33 & 0.04 \\
SEW & 0.66 & 0.65 & 0.47 \\
\hline
\end{tabular}

Table B.6 Analysis of the cross-validated redundancy $\mathrm{Q}^{2}$ (Stone Geisser criterion)

\begin{tabular}{ll}
\hline Latent variables & $\mathrm{Q}^{2}$ \\
\hline Job satisfaction & 0.08 \\
Organ. commitment & 0.15 \\
SEW & 0.37 \\
\hline
\end{tabular}


Fig. B.1 SEW framework for mediation

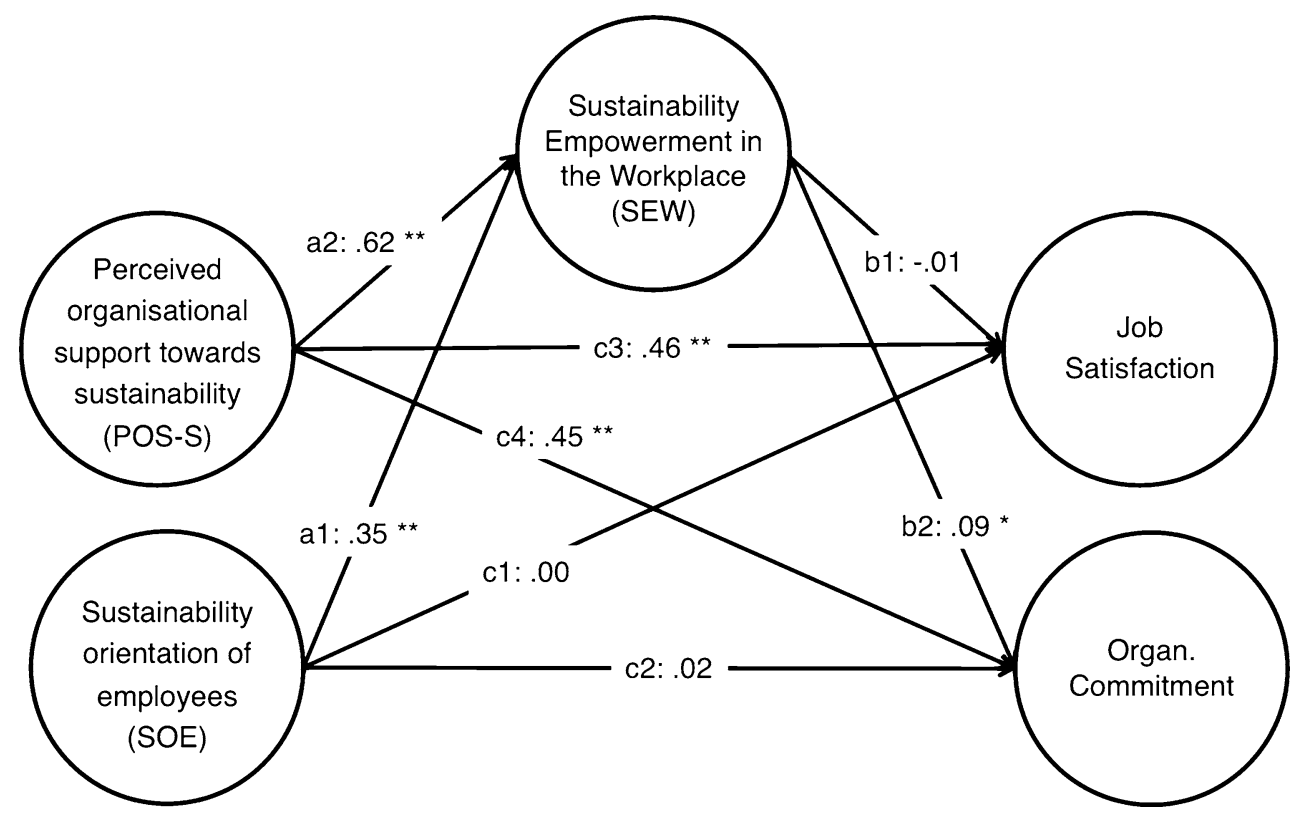

Table B.7 Variance inflation factor (VIF) of the structural model

\section{Determinants of SEW}

Hypotheses

Latent variables

VIF

H1

POS-S $\rightarrow$ SEW

1.09

$\mathrm{H} 2$

$\mathrm{SOE} \rightarrow \mathrm{SEW}$

1.09

Effects of SEW

Hypotheses

Latent variables

VIF

$\mathrm{H} 3 \mathrm{a}$

$\mathrm{SEW} \rightarrow$ Job satisfaction

1.00

$\mathrm{H} 3 \mathrm{~b}$

$\mathrm{SEW} \rightarrow$ Organ. commitment

1.00

Table B.8 Total indirect effects in the mediating test

\begin{tabular}{llc}
\hline Total indirect effects $(\mathrm{a} * \mathrm{~b})$ & $\begin{array}{l}\text { Product } \\
\text { coefficient }\end{array}$ & $p$-value \\
\hline $\begin{array}{l}\mathrm{SOE}(\mathrm{a} 1) \rightarrow \text { SEW } \rightarrow \text { Job satisfac- } \\
\text { tion }(\mathrm{b} 1)\end{array}$ & 0.00 & 0.90 \\
$\begin{array}{l}\mathrm{SOE}(\mathrm{a} 1) \rightarrow \text { SEW } \rightarrow \text { Organ. com- } \\
\text { mitment (b2) }\end{array}$ & 0.03 & 0.04 \\
$\begin{array}{l}\text { POS-S (a2) } \rightarrow \text { SEW } \rightarrow \text { Job satis- } \\
\text { action (b1) }\end{array}$ & 0.00 & 0.90 \\
$\begin{array}{l}\text { POS-S (a2) } \rightarrow \text { SEW } \rightarrow \text { Organ. } \\
\text { commitment (b2) }\end{array}$ & 0.05 & 0.04 \\
\hline
\end{tabular}

Table B.9 Direct effects in the mediating test

\begin{tabular}{lll}
\hline Direct effects (c) & $\begin{array}{l}\text { Path } \\
\text { coefficient }\end{array}$ & $p$-value \\
\hline SOE $\rightarrow$ Job satisfaction (c1) & 0.00 & 0.97 \\
SOE $\rightarrow$ Organ. commitment (c2) & 0.02 & 0.55 \\
POS-S $\rightarrow$ Job satisfaction (c3) & 0.46 & $<0.01$ \\
POS-S $\rightarrow$ Organ. commitment & 0.45 & $<0.01$ \\
$(\mathrm{c} 4)$ & & \\
\hline
\end{tabular}

Analysis of the inner (structural) model

a) Evaluation of Path Coefficients and their Significance (Table B.3)

The threshold values for the quality measure $(\geq 0.2$, Chin 1998, p. 11) are fulfilled.

b) Moderation Effect of the Sustainability-Orientation of Employees (SOE) (Table B.4)

c) Explanatory and Predictive Power of the Model (Table B.5)

$\mathrm{R}^{2}$ must have a minimum value of 0.19 Chin (1998, p. 323).

\section{d) Cross-Validated Redundancy $\mathbf{Q}^{2}$ or Stone Geisser Criterion (Table B.6)}

If $\mathrm{Q}^{2}$ is greater than zero, the model has an estimation relevance (Ringle 2004, p. 16).

\section{e) Multicollinearity Test with Variance Inflation Factor (VIF) (Table B.7) \\ (VIF value should be <10) (Herrmann et al. 2007, p. 111).}

\section{Assessment of the overall model}

The evaluation of the overall model via a "globally applicable criterion for assessing model quality" is currently not possible with the PLS approach (Weiber and Mühlhaus 2014 , p. 325). It is therefore recommended to consider the quality of the overall model in an "overall view" of var- 
ious individual criteria of the measurement and structural model. In particular, Chin (1998) recommends the quality measure for predictive validity based on the Stone Geisser criterion $\mathrm{Q}^{2}$. The coefficient of determination $\mathrm{R}^{2}$ can also be used as a measure for assessing the explanatory power of a structural model for the overall evaluation (Nitzl 2010). If the relevant quality criteria are considered fulfilled in all areas of the measurement and structural model, the overall model can also be considered reliable.

Current research in the PLS research community is working on the construction of quality criteria for the assessment of PLS overall models and discuss their application. Here, Henseler et al. (2014) see in particular the quality measures SRMR (Standardized Root Mean Square Residual) as relevant mean values of a PLS overall model. The SRMR value for the model is 0.09 , and it can be assumed that the model has a good quality according to the Hu \& Bentler (1999) requirement that SRMR should be less than 0.10. To summarize, the requirements in the literature for a total quality of a PLS model (Ringle 2004; Henseler et al. 2014) can be confirmed by the present model.

\section{Mediating effect of SEW}

In the evaluation of mediating effects in PLS analysis the authors follow the model suggested in the literature (e.g. Zhao et al. 2010; Hair et al. 2017; Nitzl et al. 2016). For this it was necessary to create a new structural model which contains also the direct path connections from the exogenous latent to the two endogenous latent variables integrating SEW as a mediator variable (Fig. B.1).

The testing of mediating effects is a two-step test procedure. In the first step, the significance of the indirect effect is checked. The coefficient results from the multiplication of the two paths a and $b$ (Table B.8).

The results of step 1 show that there are two significant indirect effects in the model both related to organisational commitment. The indirect effects towards job satisfaction are not significant.

In the second step, it is necessary to calculate the significance of the direct path between the exogenous and endogenous variables $(\mathrm{c})$.

Table B.9 shows that there is an insignificant direct effect between sustainability-orientation of employees (SOE) and organisational commitment. In this case, the model of Zhao et al. (2010) determines that in regard to the results of the first step, it is a complete mediation. It can therefore be said that SEW acts as a complete mediator between SOE and organisational commitment. The results also show that the direct effect between POS-S and organisational commitment is significant. The authors can explain that SEW acts as a partial mediator between the determinant POS-S and the consequence organisational commitment.

\section{References}

Aguinis H, Glavas A (2012) What we know and don't know about corporate social responsibility: a review and research agenda. J Manage 38:932-968

Ashforth BE, Mael F (1989) Social identity theory and the organization. AMR 14:20

Bentein K, Stinglhamber F, Vandenberghe C (2002) Organization-, supervisor-, and workgroup-directed commitments and citizenship behaviours: A comparison of models. Eur J Work Organ Psychol 11(3):341-362

Blazejewski S, Dittmer F, Graef A, Herbes C (2014) Pro-environmental Intrapreneurship: the role of life-work identity spill-over effects. Acad Manag Proc 1:13656

Bliesner A, Liedtke C, Rohn H (2013) Change Agents für Nachhaltigkeit: was müssen sie können? Z Führung Organ 82(1):49-53

Boudreau JW (2003) Sustainability and the talentship paradigm: strategic human resource management beyond the bottom line. CAHRS working paper series. Paper 40. http://digitalcommons.ilr.cornell. edu/cahrswp/40. Accessed 6 Oct 2019

Brammer S, Millington A, Rayton B (2007) The contribution of corporate social responsibility to organisational commitment. Int $\mathrm{J}$ Hum Resour Manag 18(10):1701-1719

Buerke A, Weinrich K, Kirchgeorg M (2013) Wenn Werte entscheiden. Ein Ansatz zur Identifizierung von Nachhaltigkeitstalenten im Employer Branding auf Basis persönlicher Werte. Unternehmung 67(2): 194-217

Buhl A, Schmidt-Kelich M, Muster V, Blazejwski S, Schrader U, Harrach C, Schäfer M, Süßbauer E (2019) Design thinking for sustainability: Why and how design thinking can foster sustainability-oriented. Journal of Cleaner Production 231(10):1248-1257

Buhr M (2015) Change Agents für unternehmerische Nachhaltigkeit Individuen als Gestalter/-innen nachhaltiger Veränderungsprozesse in Unternehmen. CSM-Impulse (1/2015):4-5

Cammann C, Fishman Jenkins MGD, Klesh JR (1983) Assessing the attitudes and perceptions of organizational members. In: Seashore S, Lawler E, Mirvis H, Cammann C (eds) Assessing organizational change: a guide to methods, measures, and practices. John Wiley, New York, pp 71-138

Carless SA (2004) Does psychological empowerment mediate the relationship between psychological climate and job satisfaction. J Bus Psychol 18:405-425

Carmeli A, Brammer S, Gomes E, Tarba SY (2017) An organizational ethic of care and employee involvement in sustainabilityrelated behaviors: A social identity perspective. J Organ Behav 38(9):1380-1395

Chin WW (1998) The partial least squares approach to structural equation modeling. Mod Methods Bus Res 295(2):295-336

Ciocirlan CE (2016) Environmental workplace behaviors: definition matters. Organ Environ 30(1):51-70

Daskalakis S, Mantas J (2008) Evaluating the impact of a service-oriented framework for healthcare interoperability. In: Anderson SK, Klein GO, Schulz S, Aarts J, Mazzoleni MC (eds) eHealth beyond the horizon-get IT there: Proceedings of MIE2008 (Studies in Health Technology and Informatics). IOS Press, Amsterdam, pp 285-290

De Roeck K, Maon F (2018) Building the Theoretical Puzzle of Employees' Reactions to Corporate Social Responsibility: An Integrative Conceptual Framework and Research Agenda. J Bus Ethics 149(3):609-625

De Roeck K, Stinglhamber GMF, Swaen V (2013) Understanding employees' responses to corporate social responsibility: mediating roles of overall justice and organisational identification. The International Journal of Human Resource Management 25(1):91-112

Dhanesh GS (2014) CSR as Organization-Employee Relationship Management Strategy. Management Communication Quarterly 28(1):130-149 
Edwards J, Rothbard N (2000) Mechanisms linking work and family: clarifying the relationship between work and family constructs. AMR 25(1):178-199

Elkington J (2013) Enter the triple bottom line. In: The triple bottom line. Routledge, London, pp 23-38

Farooq O, Payaud M, Merunka D, Valette-Florence P (2014) The impact of corporate social responsibility on organizational commitment: exploring multiple mediation mechanisms. J Bus Ethics 125(4):563-580

Fornell C, Larcker DF (1981) Evaluating structural equation models with unobservable variables and measurement error. J Mark Res $18: 39-50$

Galpin T, Whitttington JL, Bell G (2015) Is your sustainability strategy sustainable? Creating a culture of sustainability. Corporate Governance 15(1):1-17

Glavas A (2016) Corporate social responsibility and organizational psychology: an integrative review. Front Psychol 7:144

Glavas A, Kelley K (2014) The effects of perceived corporate social responsibility on employee attitudes. Bus Ethics Q 24(2):165-202

Gond JP, El Akremi A, Swaen V, Babu N (2017) The psychological microfoundations of corporate social responsibility: a person-centric systematic review. J Organiz Behav 38(2):225-246

Greening DW, Turban DB (2000) Corporate social performance as a competitive advantage in attracting a quality workforce. Bus Soc 39(3):254-280

Hair JF, Hult GTM, Ringle CM, Sarstedt M (2017) Partial Least Squares Strukturgleichungsmodellierung, (PLS-SEM), 2nd edn. Vahlen, München

Harrach C, Scharder U, Buhl A (2019) Design thinking for sustainability: Mit Design Thinking Nachhaltigkeitsempowerment von Mitarbeiter(inne)n am Arbeitsplatz fördern. In: Becke G (ed) Gute Arbeit und ökologische Innovationen. Perspektive nachhaltiger Arbeit in Unternehmen und Wertschöpfungsketten. Oekom, München, pp 141-158

Harrach C, Schrader U, Stanszus L, Muster V (2014) Nachhaltige Werte am Arbeitsplatz lohnen sich. Ökol Wirtsch 1.2014:12-13

Harris J, Wheeler A, Kacmar K (2009) Leader-member exchange and empowerment: direct and indirect effects on job satisfaction, turnover intentions, and performance. Leadersh Q 20:371-382

Haws KL, Winterich KP, Naylor RW (2014) Seeing the world through GREEN-tinted glasses: Green consumption values and responses to environmentally friendly products. Journal of Consumer Psychology 24(3):336-354

Hejjas K, Miller G, Scarles C (2018) "It's like hating puppies!” Employee disengagement and corporate social responsibility. J Bus Ethics. https://doi.org/10.1007/s10551-018-3791-8

Henseler J, Dijkstra TK, Sarstedt M, Ringle CM, Diamantopoulos A, Straub DW, Calantone RJ (2014) Common beliefs and reality about PLS: Comments on Rönkkö and Evermann (2013). Organ Res Methods 17(2):182-209

Henseler J, Ringle CM, Sarstedt M (2012) Using partial least squares path modeling in advertising research: basic concepts and recent issues. Handbook of research on international advertising, vol 252

Herrmann A, Gassmann O, Eisert U (2007) An empirical study of the antecedents for radical product innovations and capabilities for transformation. Journal of Engineering and Technology Management 24(1-2): $92-120$

Hesselbarth C, Schaltegger S (2014) Educating change agents for sustainability-learnings from the first sustainability management master of business administration. J Clean Prod 62:24-36

Höck M, Ringle CM (2006) Strategic networks in the software industry: an empirical analysis of the value continuum. IFSAM VIIIth World Congress, Berlin, 2006 (http://www.ibl-unihh.de/ IFSAM06.pdf, downloaded 29.08.2018)

Hofman PS, Newman A (2014) The impact of perceived corporate social responsibility on organizational commitment and the moderating role of collectivism and masculinity: evidence from China. Int J Hum Resour Manag 25:631-652
Hu LT, Bentler PM (1999) Cutoff criteria for fit indexes in covariance structure analysis: Conventional criteria versus new alternatives. Structural Equation Modeling: A Multidisciplinary Journal 6(1):1

Jones DA, Newman A, Shao R, Cooke FL (2019) Advances in employee-focused micro-level research on corporate social responsibility: situating new contributions within the current state of the literature. J Bus Ethics 157(2):293-302

Judge TA, Hurst C (2007) Capitalizing on one's advantages: role of core self-evaluations. J Appl Psychol 92:1212-1227

Kahn WA (1990) Psychological conditions of personal engagement and disengagement at work. Acad Manag J 33:692-724

Kirchgeorg M (2004) Talents for Sustainability. IManagement mit Vision und Verantwortung. Gabler, Wiesbaden, pp 645-663

Kraimer ML, Seibert SE, Liden RC (1999) Psychological empowerment as a multidimensional construct: A test of construct validity. Educational and Psychological Measurement 59:127-142

Kramer MR, Porter M (2011) Creating shared value. Harv Bus Rev 89(1/2):62-77

Lamm E, Tosti-Kharas J, King CE (2015) Empowering employee sustainability: perceived organizational support toward the environment. J Bus Ethics 128(1):207-220

Lastovicka JL, Bettencourt LA, Hughner RS, Kuntze RJ (1999) Lifestyle of the tight and frugal: Theory and measurement. Journal of consumer research 26(1):85-98

Liden RC, Wayne SJ, Sparrowe RT (2000) An examination of the mediating role of psychological empowerment on the relations between the job, interpersonal relationships, and work outcomes. J Appl Psychol 85:407-416

Lin CP, Lyau NM, Tsai YH, Chen WY, Chiu CK (2010) Modeling corporate citizenship and its relationship with organizational citizenship behaviors. J Bus Ethics 95(3):357-372

Lohmöller J-B (1989) Latent variable path modeling with partial least squares. Springer, New York

Maynard MT, Gilson LL, Mathieu JE (2012) Empowerment-fad or fab? A multilevel review of the past two decades of research. J Manage 38(4):1231-1281

Muster V, Schrader U (2011) Green work-life balance: a new perspective for green HRM. Ger J Res Hum Resour Manag 25(2):140-156

Nitzl C (2010) Eine anwenderorientierte Einführung in die Partial Least Square (PLS)-Methode. Universität Hamburg, Institut für Industrielles Management, Hamburg

Nitzl C, Roldán JL, Carrión CG (2016) Mediation analysis in partial least squares path modeling: helping researchers discuss more sophisticated models. Ind Manag Data Syst 119(9):1849-1864

Orlitzky M, Siegel DS, Waldman DA (2011) Strategic corporate social responsibility and environmental sustainability. Bus Soc 50(1):6-27

Peterson DK (2004) The relationship between perceptions of corporate citizenship and organizational commitment. Bus Soc 43(3):296-319

Ramus CA, Killmer AB (2007) Corporate greening through prosocial extrarole behaviours-a conceptual framework for employee motivation. Bus Strat Env 16(8):554-570

Ramus CA, Steger U (2000) The roles of supervisory support behaviors and environmental policy in employee "Ecoinitiatives" at leadingedge European companies. AMJ 43(4):605-626

Respondi AG (2018) Unsere Antworten auf die 28 ESOMAR-Fragen zur Bestimmung der Qualität von Online Samples und Online Panels. https://www.respondi.com/wp-content/uploads/2018/ 04/Alle_Brosch\%C3\%BCren_2018.pdf. Accessed 3 Oct 2019

Rhoades L, Eisenberger R, Armeli S (2001) Affective commitment to the organization: the contribution of perceived organizational support. J Appl Psychol 86(5):825-836

Rich BL, LePine JA, Crawford ER (2010) Job engagement: antecedents and effects on job performance. Acad Manag J 53:617635 
Rich GA (1997) The sales manager as a role model: effects on trust, job satisfaction, and performance of salespeople. J of the Acad Mark Sci 25:319-328

Ringle CM (2004) Gütemaße für den Partial-least-squares-Ansatz zur Bestimmung von Kausalmodellen. Univ. Hamburg, Inst. für Industriebetriebslehre und Organisation, Arbeitsbereich Industrielles Management, Hamburg

Ringle CM, Wende S, Becker J-M (2015) SmartPLS 3. Boenningstedt: SmartPLS GmbH. http://www.smartpls.com. Accessed 4 Nov 2019

Rupp DE, Mallory DB (2015) Corporate social responsibility: Psychological, person-centric, and progressing. The Annual Review of Organizational Psychology and Organizational Behavior 2(1):211-236

Schrader U, Harrach C (2013) Empowering responsible consumers to be sustainable intrapreneurs. In: Schrader U, Fricke V, Doyle D, Thoresen V (eds) Enabling responsible living. Springer, Heidelberg, pp 181-192

Seibert SE, Wang G, Courtright SH (2011) Antecedents and consequences of psychological and team empowerment in organizations: a meta-analytic review. J Appl Psychol 96(5):981-1003

Shamir B (1991) Meaning, self and motivation in organizations. Organ Stud 12(3):405-424

Sheldon KM, Elliot AJ (1999) Goal striving, need satisfaction, and longitudinal well-being: The self-concordance model. Journal of Personality and Social Psychology 76(3):482-497

Spreitzer GM (1995) Psychological empowerment in the workplace: dimensions, measurement, and validation. Acad Manag J 38(5):1442-1465

Spreitzer GM, Kizilos MA, Nason SW (1997) A dimensional analysis of the relationship between psychological empowerment and effectiveness satisfaction, and strain. Journal of management 23(5):679-704

Tariq S, Jan FA, Ahmad MS (2016) Green employee empowerment: a systematic literature review on state-of-art in green human resource management. Quality \& Quantity 50(1):237-269
Thomas KW, Velthouse BA (1990) Cognitive elements of empowerment: An "interpretive" model of intrinsic task motivation. Academy of Management Review 15(4):666-681

Turker D (2009) How corporate social responsibility influences organizational commitment. J Bus Ethics 89:189-204

Valentine S, Fleischmann G (2008) Ethics programs, perceived corporate social responsibility and job satisfaction. $\mathrm{J}$ Bus Ethics 77(2): 159-172

Visser W, Crane A (2010) Corporate sustainability and the individualUnderstanding what drives sustainability professionals as change agents (Available at SSRN 1559087)

Vlachos PA, Panagopoulos NG, Rapp AA (2014) Employee judgments of and behaviors toward corporate social responsibility: A multistudy investigation of direct, cascading, and moderating effects. Journal of Organizational Behavior 35(7):990-1017

Weaver GR, Treviño LK, Cochran PL (1999) Corporate ethics programs as control systems: influences of executive commitment and environmental factors. Acad Manag J 42:41-57

Weiber R, Mühlhaus D (2014) Strukturgleichungsmodellierung: Eine anwendungsorientierte Einführung in die Kausalanalyse mit Hilfe von AMOS, SmartPLS und SPSS. Springer, Berlin Heidelberg

Weinrich K (2014) Arbeitgeberwahl aus verhaltenstheoretischer Sicht. In: Nachhaltigkeit im Employer Branding. Springer Gabler, Wiesbaden, pp 119-147

Wold H (1982) Soft modeling: the basic design and some extensions. In: Jöreskog KG, Wold H (eds) Systems under indirect observations: causality, structure, prediction, part II. North Holland Publishing Company, Amsterdam, pp 1-54

Zhao X, Lynch JG, Chen Q (2010) Reconsidering Baron and Kenny: myths and truths about mediation analysis. J Consumer Res 37(2):197-206 